International Research Journal of Management, IT \& Social Sciences
Available online at https://sloap.org/journals/index.php/irjmis/
Vol. 5 No. 6, November 2018, pages: $60 \sim 70$
ISSN: 2395-7492
https://doi.org/10.21744/irjmis.v5n6.373

\title{
Attitude, Intention, and Consumer Behaviour of Millennial Generation toward Location-Based SMS Advertising
}

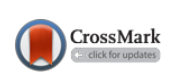

I Made Sindhu Yoga a

I Gusti Ngurah Darma Paramartha ${ }^{b}$

\section{Article history:}

Received: 5 July 2018

Accepted: 30 September 2018

Published: 9 November 2018

\section{Keywords:}

Advertisement;

Consumer behaviour;

Location-based advertising;

Millennial generation;

SMS;

\begin{abstract}
The aim of this study is to ascertain the attitude, intention and consumer behaviour of millennial generation toward the implementation of marketing communication by using Short Message Service (SMS) technology according to consumer location. In current technological developments, the promotion strategy, particularly advertising, has adapted through various digital marketing media. Mobile marketing, one of them is SMS Advertising still used by various companies in order to increase potential consumer awareness as the first step to trial product and encourage the purchases. Several previous types of research discovered that most consumer attitude toward the SMS advertising tends to be negative. Moreover, SMS with Location-based advertising service disturb consumer privacy. This study tries to see the indicators which can be optimized to develop attitudes, intention and positive behaviours and the affordable effort as a suggestion that the advertisements can be delivered by SMS with location-based advertising services and more effective to get attention and accepted by consumers of the millennial generation.
\end{abstract}

2395-7492@ Copyright 2018. The Author. This is an open-access article under the CC BY-SA license (https://creativecommons.org/licenses/by-sa/4.0/) All rights reserved.

\section{Author correspondence:}

I Made Sindhu Yoga,

Universitas Pendidikan Nasional, Denpasar, Indonesia

Email address: madesindhu@undiknas.ac.id

\section{Introduction}

Mobile phone or these days well-known as smartphone continually transformed from time to time. At the beginning of its emersion, it only has the main function to call and send messages. Along with its development, the function to send message become excellent value-added compared with a phone cable. The message can be sent via smartphone or called as SMS (Short Message Service). According to Leung (2007), SMS is short message system facility in every mobile phone and can be used by every user to send, receive, save the message or to forward into message form consists of 160 characters.

\footnotetext{
a Universitas Pendidikan Nasional, Denpasar, Indonesia

${ }^{\mathrm{b}}$ Universitas Pendidikan Nasional, Denpasar, Indonesia
} 
A millennial generation or Y generation is a group of generations that were born, grew, and developed along with the evolution of mobile phones. Nowadays, the existence of the smartphone in the millennial generation group is not only carrying on its main function, but it becomes an inseparable part of life. If it is analogous, the smartphone has functioned as the personal assistant of this group. Chatting, texting, and selfie become a part of their lifestyle and characteristics. Certainly, for the marketers, it becomes chances since the smartphone as a new media to promoting the marketing message of their products.

According to Ristekdikti Pers Announcement in 2nd of January 2017, stated that the number of smartphone users in Indonesia currently reach about $25 \%$ of the total population or about more than 65 million people. That amount is a potential number for the marketers to directly reach to their consumers. In Bali, particularly in Denpasar as the provincial capital city, and also as an urban area, the smartphone development increased from year to year. Based on BPS (Central Bureau of Statistic) data, the smartphone users' percentage in the city reached $70.4 \%$ in 2015 from the total population of residences of Bali Province.

The growth of smartphone users surely become the chance for marketers to promote marketing messages of their products, such as goods or services. A millennial generation is a group of the biggest phone users since technology evolution movement which is signed by the emersion of the internet at the beginning of 90's and smartphone development at the beginning of the 2000's. For marketers, the technology advancement which affects consumer behaviour in the decision-making process can be its own chance (Adnani et al., 2018). The conventional promotion media is not completely able to maximize in gaining attention and awareness of this consumers group. They are insufficient by only reached through mass communication, but it must be able to reach personally. Then, SMS emersion becomes an alternative media to reach consumers personally. Certainly, it becomes one of media communication which can provide answers for marketers in interferences to get the attention of consumers through mass communication media. By elaborating GPS (Global Positioning System) technology in a smartphone, SMS can be combined with location-based advertising service, so it can possibly reach target consumers geographically. Furthermore, this technology maximally can send an advertisement in form of accurate text in the target area. So that, the marketers can conveys their product advertisement in a location of their potential target consumers

Many companies in countries success in apply marketing communication through SMS integrated with locationbased advertising service or well-known as location-based SMS advertising (SMS LBA). Hossain and Bahar (2015), in their research, fasten that business in several countries in Asia, such as China, Malaysia, Singapore, and others report that marketing communication through a smartphone is growing rapidly and successfully practiced. Shadkam (2017), added that even though technology is steadily caused content, service and online entertainment evolution provided on a smartphone, but SMS facility still on lead rather than other marketing communication media. SMS is available from 20 years ago and still on developing to be the king of communication media in the world, overflow the call telephone system and face-to-face communication.

Invisibly, most consumers behaviour to advertisement via SMS tend to be negative, but marketers still believe that advertising through SMS imply that they have to consider various strategy and planning to make a content in SMS to be more attractive, so they continuously looking for another way to make it conveyed through SMS be more effective and get attention and accepted by the consumers. According to these, this study will analyze the attitude, intention and consumers behaviours, particularly on millennial generation group as generation group which was born, grown and developed along with the smartphone development to the message of marketing communication in form of SMS which is sent personally by phone to phone via location-based SMS advertising facility.

\section{Materials and Methods}

\section{Location-based Advertising}

Simply, location-based advertising (LBA) can mean as a way of marketers to convey and control the marketing information which is customized by using media, i.e. SMS to target consumer phone based on geographical location. Through this way, ad message can be personalized and send to the specific consumer along with target consumer regarding the time and location as they want. The message that is already suited to the delivery location, tend to has consumer characteristics which related to the activity and interest of target consumers. This will make the marketers easy to stimulate consumer emotionally and psychologically and widen the reach area marketing in promoting the ad message rather than conventional media.

Yoga, I. M. S., \& Paramartha, I. G. N. D. (2018). Attitude, intention, and consumer behaviour of millennial generation toward location-based SMS advertising. International Research Journal of Management, IT and Social Sciences, 5(6), 60-70. https://doi.org/10.21744/irjmis.v5n6.373 
According to Bauer et al., (2005), there are four factors that make LBA as effective marketing communication, such as:

a) Personalize the content message according to visited consumer's characteristics in the target location

b) Mobile phone users are everywhere, so it can be sure that once the sent message based on location would be received by every person in that area.

c) There is a possibility that interaction between advertiser and receiver occurs

d) The location-based message will stimulate the impulsive purchases in the store around the place where the message is received

\section{SMS Advertising}

According to Zhang and Mao (2008), explained that SMS Advertising is a part of mobile marketing which use SMS technology and gives a chance to the marketers to send a personal message directly to the phone user. Based on Leung (2007) statement, SMS is a popular form of advertisement through a mobile phone. This instant message system is supported by almost every mobile phone provider. This is possible for them to receive, saving and forward alphanumeric message up to 160 characters to mobile phone based on GSM (Global System for Mobile Communication). Besides, the provider of telecommunication service has elaborate GPS (Global Positioning System) technology in the mobile phone, so it could be able to reach a consumer with right information based on time and specific location. This could make ad via SMS become more effective and efficient, moreover, it can make an easy way for marketers in promoting their product, thing or service which can be suited with the consumers' personal necessity, such as content, message which due to consumer need become the company target.

Liu et al., (2011), described that ad content through mobile phone consists of three main factors; infotainment, irritation, and credibility toward the ad which influence the way the consumer assess the product and evaluation. The three factors build from several previous types of research done by experts such as Okazaki (2004); Wang and Sun (2010) in Liu et al., (2011) is described that variable informativeness and entertainment are integrated into one variable, infotainment. It is mentioned that irritation variable is related to negative respond of the ad value and credibility is built in Choi et al., (2008) research which stated that the trust of consumers toward the ad is assessed through the delivered messages

Besides those three factors, consumers tend to more open in receiving information through SMS, if the message was received at the right time and place. According to Gidofalvi et al., (2008), the ad message can be created contextually by identify the location in the specific time. According to this, there are four factors which develop SMS advertising variable used in this study:

a) Infotainment. Information can mean like the ability of the ad to convey the message to the consumer in order to fulfill their needs toward a thing or service. Messages bring the information and raise the awareness of target consumer about information which probably they needed. Based on Nasco and Bruner (2008), a message that was sent through mobile phone need a feature such as punctuality of delivery and it should give information that is usable for the consumers. Chowdhury et al., (2006), mentioned that the element of entertainment on message could increase the loyalty of consumers and giving add-value for them. The ad with entertain element could create an impression and positive impact toward consumers perception on the advertisement. In another word, it means that infotainment is a combination of a message with the right information and useful to answer the target consumer needs with writing and language style which able to entertain them.

H1: Infotainment in location-based SMS advertising has a positive impact toward consumer's behaviour in receiving SMS advertising

b) Irritation. Most consumers are still feeling uncomfortable with a message which delivered via SMS advertising. They tend to think about doing the received ad in their phone offer the proper and safe product, thing or service? Besides, this also makes consumers think that the location and existence and also their behavior can be controlled and watching out. This phenomenon explains the reaction as a response of irritation toward their privacy which makes consumers feel unsteady about the message in ad through SMS and tend to have a negative reaction. So, it can be concluded that the irritation will create an impact from not demand of the consumer to receive an ad in their mobile phone. 
H2: irritation through location-based SMS advertising has negative impact toward consumer behaviour in receiving SMS advertising.

c) Credibility. According to Waldt et al., (2009), credibility in the advertisement is related to the trust of the consumer toward a specific brand of an ad. Credibility can be assumed as an important part to figure the consumer demand on it. It means that the advertiser conveys a message and substance in SMS advertising is very important to get the trust of consumers. Okazaki et al., (2007) also emphasize the relevance and credibility of advertisement are important while consumer needs to make a decision in taking action according to uncertain information.

H3: The credibility in location-based SMS advertising has a positive effect on consumer's attitude of consumers in receiving SMS advertising

d) The Situation of time and place. Salehi (2013) stated that in purchasing process tend to relate to time accuracy, the condition of time and place in delivering SMS Advertising become an important aspect in considering the specific and unique situation. Ferris (2017) has an example that in delivering process of SMS Advertising message received by consumers phone while they pass a restaurant in lunch time. It was expected that at that moment is right to give an add-value to answer needs and demand of consumers in right time and place. According to Merisavo et al., (2007), delivering promotion message in relevant time and place is one of the strong boosters for consumers attitudes to receiving an SMS advertising. According to this thing, it can be claimed that condition of time and place where consumers receive a message have an important influence on consumers behaviour.

H4: the condition of time and place where consumer receive location-based SMS advertising have a positive effect on consumers behavior in receiving the message.

\section{Sales Promotion}

Sales Promotion is a part of marketing communication (promotion mix). The marketing communication intended to pursue people to think, feel or act in a particular way in their relationship with the brand. According to Kotler and Keller (2012), sales promotion is a way to communicate the brand marketing activity of a product including various short-term incentive in encouraging people to try or to buy the product. This approach offers an interesting opportunity to serve the phone users with a real reason to receive SMS Advertising.

Several offerings have a benefit and economic value included in SMS advertising, such as a discount, coupon and another gift which can be gained by a certain amount of purchase that applies when shown at a store or store where the goods or services are sold. Drossos et al., (2007) stated that a consumers behavior and intention to purchase have positive correlation if there is an incentive in the message in SMS Advertising. Furthermore, according to Rettie $e t$ al., (2005) various sales promotion strategy can be used to make the SMS Advertising promotion success. The offering of sales promotion program and incentive can be used to drive consumers to product purchase.

H5: sales promotion program in location-based SMS advertising has a positive effect toward consumers intention of the millennial generation to receive a message via SMS advertising.

\section{Attitude, Intention, and Consumers Behaviour of Millennial Generation}

Varshney and Joy (2015), defined attitude as the important concept in marketing and advertising in every study. Related to attitude and consumers orientation, the attitude as an object reference to product advertising concept, brand, service, and usage. Even though, their consistency and act, but this thing are temporary, and probably change according to the certain situation. Kotler and Keller (2012), stated that the increase of ad frequency via phone can easily impact the consumer's behavior changes toward a brand or specific product. Therefore, Varshney and Joy (2015) continued, in understanding consumers attitudes can help to comprehend consumers intention to purchase goods and service.

Based on Boonlert (2011), a young generation is a group of people which easiest to put interest on service provided on phones, such as SMS, WAP, MMS and other texts which can be able to make them connected. The unique character of this generation become the basis of research about location-based SMS advertising which only wants to focus on a group of young generation, i.e., Millennial generation. Kwon (2007), stated that "Millennial Generation" or well-

Yoga, I. M. S., \& Paramartha, I. G. N. D. (2018). Attitude, intention, and consumer behaviour of millennial generation toward location-based SMS advertising. International Research Journal of Management, IT and Social Sciences, 5(6), 60-70. https://doi.org/10.21744/irjmis.v5n6.373 
known as "Nintendo-Internet-Digital Generation", "Echo Generation", "Nexter", or commonly known as "Y Generation" is a generation who born in 1980 era until the beginning of 2000, in other word, this generation is production is a productive age generation with an age range from 17 years to 37 years or included in the productive generation. In Indonesia, this generation range can be described as generation group who pioneer a new career in industry, while developing their business or start to be an entrepreneur, a collegian or still preparing themselves to be a scholar. Many of them are a newlywed. The youngest group of this generation is in a transition period from teenager to be adult.

This generation becomes the witness of internet and phone emersion. This can be said that this generation was born, grown and developed along with internet and phone which become an inseparable part of their life. Their attitudes, intention, and behavior are influenced by the internet and phone and other media. Texting, chatting, and selfie becomes an inherent activity in their social life. The millennial generation is connected through technology which makes an easy access to information and integration of communication.

According to Shadkam (2017), generally, consumers received SMS advertising tend to open and read the message as soon as they received it on their phone. Consumers behavior that arises from this reaction after receive the message can be negative which is marked by ignore the message or soon to delete it, even before after reading the message. While, positive consumers behavior will be marked by responding to the message, for example by saving it first, forward it to other or purchasing according to the content. Mimosette and Paul (2015), stated that it is very important for marketers to understand the relation between attitudes and intention of consumers in receiving SMS Advertising toward its impact on behavior after receiving it.

H6: the attitudes toward Location-based SMS Advertising has a positive effect on the consumer of Millennial Generation intention to receive SMS Advertising.

H7: intention to receive Location-based SMS Advertising has a positive effect on consumers behaviour of Millennial Generation after receive SMS Advertising.

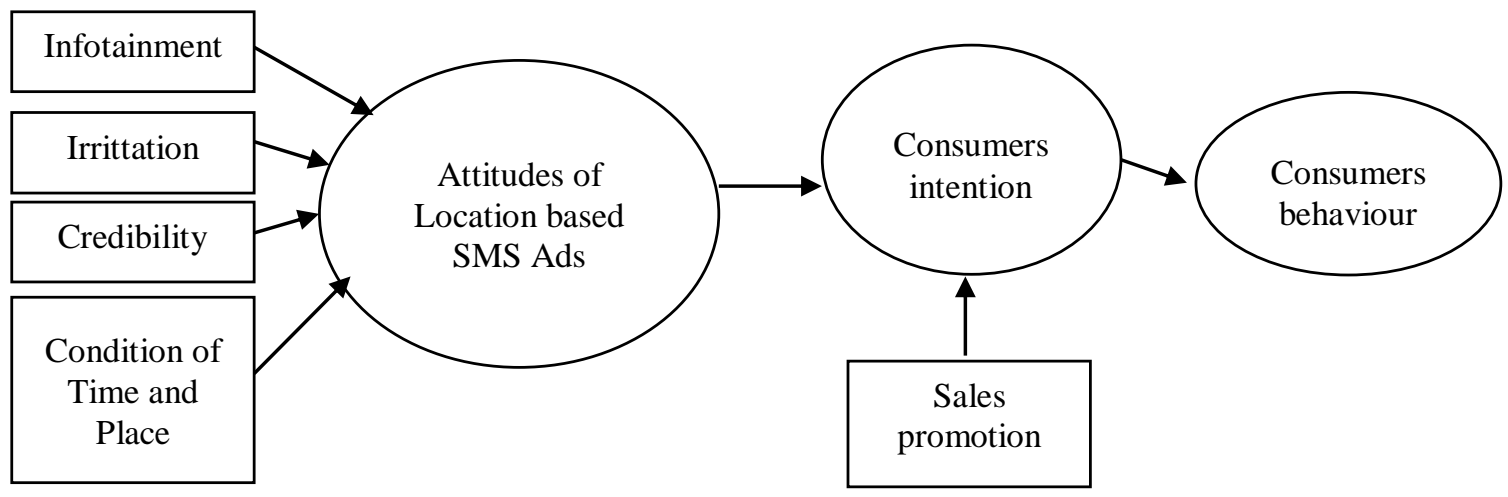

Figure 1. Research Model

\section{Results and Discussions}

The data collection in this study is done by doing questionnaires distribution in several malls/department store in Denpasar and also hang-out places by targeting millennial generation group, i.e. group of respondents who were born in the range from 1980 until 2000. Characteristics of respondents are considered in terms of demographics such as gender, age, occupation, an average of monthly income and average spending money in visiting mall or hang-out place at once.

According to gender, the comparison of male respondents and female is $43 \%$ compared to $57 \%$. The age range of respondents is based on millennial generation age range which was born from 1980 to 2000, or about 18 years old to 38 years old. In grouping, respondents with age 23 to 27 years old is the biggest amount i.e. about $48 \%$. While a group of age between 33 to 38 years old is $15 \%$ of all respondents. Based on age range percentage, the majority of respondents have an occupational background as employee and high school students or college students with $38 \%$ of each. 
The majority of respondents background as an employee have correlated with stage of majority respondents income between Rp. 2.500.000 to Rp.5.000.000 and range of income level between Rp. 5,000,000 to Rp. 7,500,000 is 30\% of the total respondents. If it is considered the majority of respondents characteristics according to age, income level, and occupation, it can be related that the average level of expenditure issued by a respondent in one time hangs out is between Rp. 100,000 to Rp. 500,000 as many as 65\% of the total respondents and followed by a range between Rp. 500,000 to Rp. 1,000,000 for each time you hang out.

According to this data, it can be noticed that respondents majority is potential target consumers in young age, middle income, and has a fairly consumptive purchasing power. For the marketers, with the potential purchasing power of consumers to be an interesting thing to be able to market products in the form of goods or services to potential consumers by choosing the right media, time, and place in order to reach them individually so that these potential consumers know about the existence of a product and interested in trying or making a purchase.

Furthermore, the test of this research is using Structural Equation Model (SEM) various based i.e. Partial Least Square (PLS). The measure model that is used to validity and reliability test and determination and path coefficient, the tested model as follows:

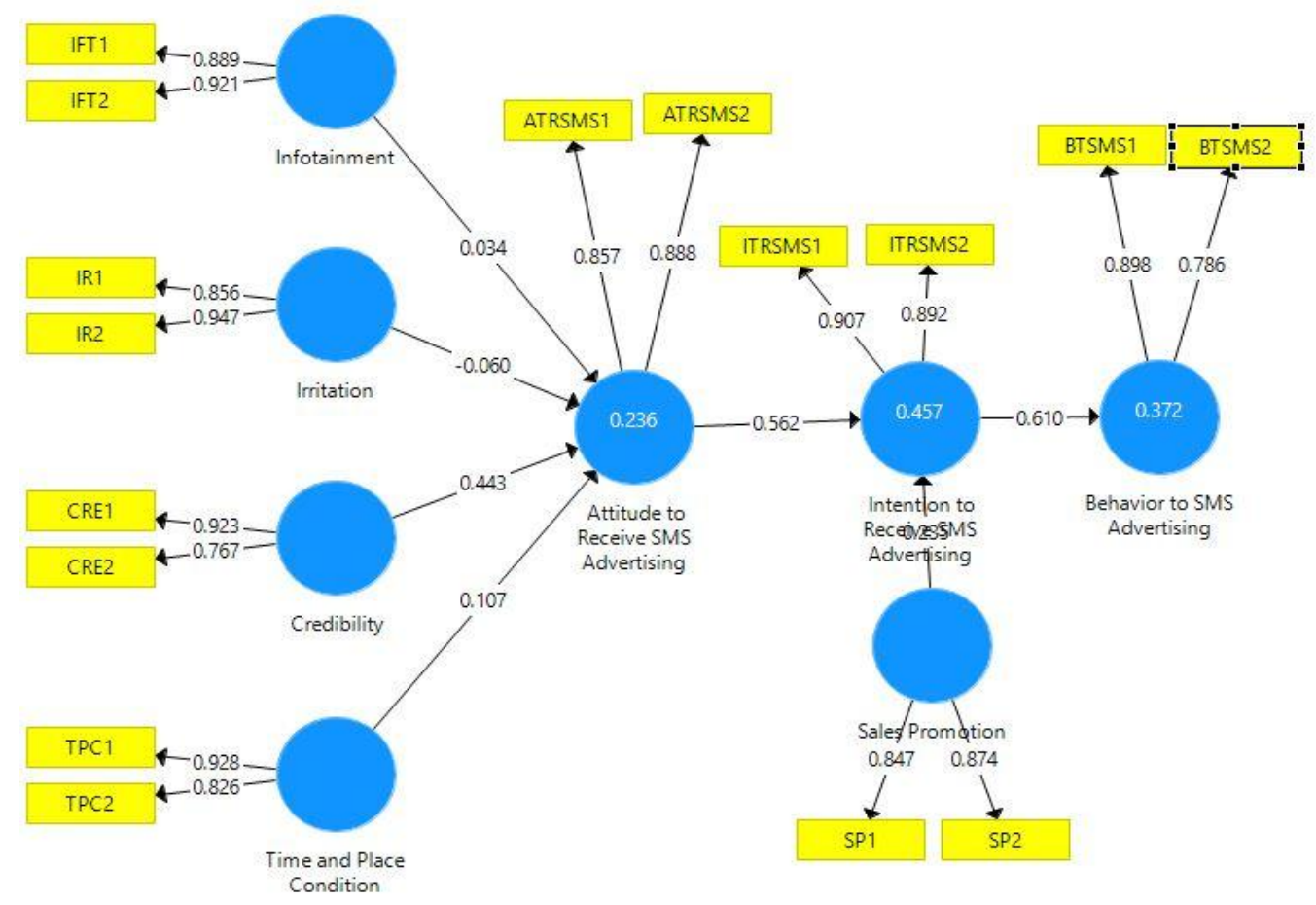

Figure 2. Path Coefficient Output

Validity testing is evaluated by using loadings factor criteria which should be significant and the result if more than 0,70 and average variance extracted (AVE) for each construct should be more various which is caused by the construct measurement error is the value exceeds 0.50 so the probability of the indicator converging to enter the construct in question is greater that is above 50 percent.

The structural model of PLS is evaluated by using $\mathrm{R}^{2}$ to construct dependent, coefficient value of path or $\mathrm{t}$-value for each path to significance test between construct in the structural model. Behaviour variable toward Location-based SMS Advertising has R-square about 0.457 which means a various change of variable of Attitudes toward Locationbased SMS Advertising can be explained by Consumers intention variable, consumers behaviour about $45.7 \%$ while the rest is explained by another variable outside the model.

Yoga, I. M. S., \& Paramartha, I. G. N. D. (2018). Attitude, intention, and consumer behaviour of millennial generation toward location-based SMS advertising. International Research Journal of Management, IT and Social Sciences, 5(6), 60-70. https://doi.org/10.21744/irjmis.v5n6.373 
Table 1

R Square and Redundancy Value

\begin{tabular}{lc}
\hline \multicolumn{1}{c}{ Variable } & R Square \\
\hline Attitudes toward Location-based SMS Advertising & 0.457 \\
Consumers intention & 0.372 \\
Consumers behaviour & 0.236 \\
\hline
\end{tabular}

Variable of consumers intention has R-square about 0.372 which means that various change of consumers intention can be explained by the attitude toward Location-based SMS Advertising, consumers behaviour about $37.2 \%$ while the rest can be explained by another variable outside the model. On the other hand, consumers behaviour variable has R-square about 0.236 which mean various change of consumers behaviour variable can be explained by attitudes toward Location-based SMS Advertising, consumers intention about 50.4\% while the rest can be explained by another variable outside the model.

This research used a trust level of about 95\%, and this research hypothesis is one-tailed hypothesis. Significant hypothesis support can use comparisons between t-table values with t-statistics. If the t-statistic value is higher compared with the t-table, it shows a supported hypothesis. At 95\% confidence level the t-table for one-tailed hypothesis exceeds 1.64. Hypothesis test results are presented in the table below.

Table 2

Path Coefficient Value on Structural Model Testing

\begin{tabular}{|c|c|c|c|c|c|}
\hline & Original Sample (0) & Sample Mean (M) & Standard Deviation (STDEV) & T Statistics (|O/STDEV|) & P Values \\
\hline Attitude to Receive SMS Advertising -> Intention to Receive SMS Advertising & 0.562 & 0.575 & 0.093 & 6.076 & 0.000 \\
\hline Credibility -> Attitude to Receive SMS Advertising & 0.443 & 0.422 & 0.166 & 2.674 & 0.008 \\
\hline Intention to Receive SMS Advertising -> Behavior to SMS Advertising & 0.610 & 0.611 & 0.088 & 6.918 & 0.000 \\
\hline Infotainment -> Attitude to Receive SMS Advertising & 0.034 & 0.036 & 0.123 & 0.273 & 0.785 \\
\hline Irritation -> Attitude to Receive SMS Advertising & -0.060 & -0.037 & 0.118 & 0.509 & 0.611 \\
\hline Sales Promotion -> Intention to Receive SMS Advertising & 0.235 & 0.226 & 0.087 & 2.699 & 0.007 \\
\hline Time and Place Condition $->$ Attitude to Receive SMS Advertising & 0.107 & 0.118 & 0.088 & 1.217 & 0.224 \\
\hline
\end{tabular}

The table above shows that the nature of the independent and dependent variables varies, the variation is indicated by the original sample value which shows positive or negative numbers, then the hypothesis is explained as follows:

H1: Infotainment in location-based SMS advertising has a positive effect toward consumer's attitudes in receiving SMS advertising. This test shows that the obtained t-statistic for this hypothesis is 0.261 which mean this value is smaller than t-table. Path coefficient value is about 0.034 which mean there is a positive correlation but insignificant between infotainment in Location-based SMS advertising toward consumers attitudes in receiving SMS Advertising, thus this hypothesis is unsupported.

H2: Irritation via location-based SMS advertising has a negative effect toward consumer's attitude in receiving SMS advertising. This test show obtained t-statistic for this hypothesis is 0.486 which mean smaller than $\mathrm{t}$ table. Path coefficient value is -0.060 which mean there is an insignificant negative correlation between irritation through Location-based SMS Advertising toward consumers attitudes in receiving SMS advertising, thus this hypothesis is unsupported.

H3: Credibility in location-based SMS advertising has a positive effect toward consumers attitudes in receiving SMS advertising. This test shows the obtained t-statistic for this hypothesis is 2.685 which mean this value is bigger than t-table. Path coefficient value is about 0.443 which mean there is a significant positive correlation between credibility in location-based SMS advertising toward consumers behaviour in receiving SMS advertising, thus this hypothesis is supported.

H4: Condition of time and place where consumers receive location-based SMS advertising has a positive effect toward consumers attitude in receiving a message through SMS Advertising. This test shows the obtained tstatistics for this hypothesis is 1.214 which mean t-table value is smaller than t-statistic. Path coefficient value is about 0.107 which mean there is an insignificant positive correlation between time condition and place 
where consumers receive location-based SMS advertising toward consumers attitude in receiving SMS Advertising, thus this hypothesis is unsupported.

H5: Sales promotion program in location-based SMS advertising has a positive effect toward consumers intention of the millennial generation in receiving a message via SMS advertising. This test shows that obtained $t-$ statistics for this hypothesis are 2.659 which mean t-statistic is bigger than t-table. Path coefficient value is 2.235 which mean that there is a significant positive correlation between sales promotion program in locationbased SMS advertising toward consumers intention of the millennial generation to receive a message via SMS advertising, thus this hypothesis is unsupported.

H6: Attitudes toward Location-based SMS Advertising has a positive effect on consumers intention of the millennial generation in receiving SMS advertising. This test shows the obtained $t$-statistics for this hypothesis is 5.991 which mean t-statistic value is bigger than t-table. Path coefficient value is 0.562 which mean there is a positive significant correlation for attitudes toward Location-based SMS Advertising. Thus, this hypothesis is supported.

H7: Intention to receive location-based SMS advertising has a positive effect toward consumers behaviour of millennial generation after receiving SMS advertising. This test shows that obtained t-statistic for this hypothesis is 6.670 which mean t-statistic value is bigger than t-table. Path coefficient value is about 0.610 which mean there is a significant positive correlation for the intention of receiving location-based SMS advertising toward consumers behaviour of Millennial generation after receiving SMS advertising. Thus, this hypothesis is supported.

\section{Conclusion}

Content is an important thing in marketing communication. Advertisement with interesting and entertaining way will attract consumers to pay attention to the text in an ad. But, this is not the case. The informative and entertained content of the message is insufficient to create a positive attitude for consumers. Then, advertisement via SMS is not disturbed the consumer. They feel interrupted by the information that exactly unneeded. Moreover, the time condition and place where SMS was delivered also create a negative attitude for consumers. This is related to irritation indicator i.e. consumers think that their privacy is disturbed because their gestures seemed to be watched. In the end, this could make the consumer feel uncomfortable toward Location-based SMS advertising which also creates negative attitudes.

However, the negative attitude towards the message content and the disruption that consumers feel can be undermined if the advertisement in SMS is sent by a brand that they have previously known so, it will create a sense of security and trust in the SMS they receive. Likewise, the feeling of being supervised will be helped by the sales promotion programs included in the advertising message. Sales promotion programs can help consumers feel more relieved because they are in a place close to the booth where the promotional program is being offered.

Overall, Location-based SMS Advertising has a positive effect on consumer attitudes towards messages in the form of advertising via SMS. This positive attitude also had a positive influence on consumers' intention to receive the SMS which in the end also had a positive impact on consumer behaviour in following up on advertisements in the form of the SMS. Based on the results of this study, things that need to be considered by marketers is that Location-based SMS Advertising will be more influential if done by brands that are already popular in consumer memory combined with sales promotion programs to encourage positive attitudes, interests, and behaviours.

\section{Conflict of interest statement and funding sources}

The authors declared that they have no competing interest. The study was financed by Directorate of Research and Community Service.

\section{Statement of authorship}

The authors have a responsibility for the conception and design of the study. The authors have approved the final article.

Yoga, I. M. S., \& Paramartha, I. G. N. D. (2018). Attitude, intention, and consumer behaviour of millennial generation toward location-based SMS advertising. International Research Journal of Management, IT and Social Sciences, 5(6), 60-70. https://doi.org/10.21744/irjmis.v5n6.373 
Acknowledgments

This research was financially supported by Direktorat Riset dan Pengabdian Masyarakat (Directorate of Research and Community Service), Direktorat Jenderal Penguatan Riset dan Pengembangan (Directorate General of Research and Development), Kementerian Riset, Teknologi, dan Pendidikan Tinggi Republik Indonesia (Ministry of Research, Technology, and Higher Education of Republic of Indonesia) who provided opportunities, and assisted during the research. 


\section{References}

Adnani, H., Subiyanto, A. A., Hanim, D., \& Sulaeman, E. S. (2018). Health promotion in clean and healthy behavior programs in traditional markets. International Research Journal of Management, IT and Social Sciences, 5(4), 4652.

Bauer, H. H., Reichardt, T., Barnes, S. J., \& Neumann, M. M. (2005). Driving consumer acceptance of mobile marketing: A theoretical framework and empirical study. Journal of electronic commerce research, 6(3), 181. http://www.ebusinessforum.gr/old/content/downloads/Baueretal_MomMarketingConsumerAccept.pdf

Choi, Y. K., Hwang, J. S., \& McMillan, S. J. (2008). Gearing up for mobile advertising: A cross-cultural examination of key factors that drive mobile messages home to consumers. Psychology \& Marketing, 25(8), 756-768.

Chowdhury, H. K., Parvin, N., Weitenberner, C., \& Becker, M. (2006). Consumer attitude toward mobile advertising in an emerging market: An empirical study. International Journal of Mobile Marketing, 1(2).

Drossos, D., Giaglis, G. M., Lekakos, G., Kokkinaki, F., \& Stavraki, M. G. (2007). Determinants of effective SMS advertising: An experimental study. Journal of Interactive advertising, 7(2), 16-27.

Ferris, M. (2007). Insights on mobile advertising, promotion, and research. Journal of Advertising Research, 47(1), 28-37.

Gidofalvi, G., Larsen, H.R. and Pedersen, T.B. (2008) “Estimating The Capacity of The Location-based Advertising Channel", International Journal of Mobile Communications, 6(3), 357-375.

Hossain, T. M. T., \& Bahar, V. S. (2015). An Exploratory Analysis of Factors Affecting the Effectiveness of SMS Advertising among young Bangladeshi Consumers. World, 5(2).

Kotler, P., \& Keller, K. L. (2003). Marketing Management New Jersey: Prentica Hall. International Eleventh Edition Lassar, Walfried.

Kwon, N. (2007). “Coming Attractions: Generation Y”. Food and Food Industries - Grocery Trade, 121, No. 5, pp. $41,43,45$.

Leung, L. (2007). Unwillingness-to-communicate and college students' motives in SMS mobile messaging. Telematics and Informatics, 24(2), 115-129.

Merisavo, M., Kajalo, S., Karjaluoto, H., Virtanen, V., Salmenkivi, S., Raulas, M., \& Leppäniemi, M. (2007). An empirical study of the drivers of consumer acceptance of mobile advertising. Journal of Interactive Advertising, 7(2), 41-50.

Mimosette, M. F. F., \& Paul, D. J. E. U. M. E. N. E. (2015). Factors explaining the adoption of mobile marketing in Cameroon: Exploratory study on the use of SMS as method of transmission of social information. African Journal of Marketing Management, 7(2), 20-31.

Nasco, S. A., \& Bruner, G. C. (2008). Comparing consumer responses to advertising and non-advertising mobile communications. Psychology \& Marketing, 25(8), 821-837.

Okazaki, S., Katsukura, A., \& Nishiyama, M. (2007). How mobile advertising works: The role of trust in improving attitudes and recall. Journal of Advertising Research, 47(2), 165-178.

Rettie, R., Grandcolas, U., \& Deakins, B. (2005). Text message advertising: Response rates and branding effects. Journal of targeting, measurement and analysis for marketing, 13(4), 304-312.

Salehi, M. (2013). An effective recommendation based on user behaviour: a hybrid of sequential pattern of user and attributes of product. International Journal of Business Information Systems, 14(4), 480-496.

Shadkam, M. (2017). Consumer's attitude to receive and response to SMS advertising. International Journal of Business Information Systems, 24(1), 69-90.

Siaran Pers Ristekdikti, http://www.dikti.go.id/smartphone-rakyat-indonesia-2/\#g1fI2EQxbYdpmDrc.99 retrieved on June 6, 2017

Sinkovics, R. R., Pezderka, N., \& Haghirian, P. (2012). Determinants of consumer perceptions toward mobile advertising - a comparison between Japan and Austria. Journal of Interactive Marketing, 26(1), 21-32.

Varshney, S., \& Joy, J. (2015). Consumer attitudes toward mobile marketing and its impact on customers. International Journal of Information, Business and Management, 7(2), 44.

Waldt, V. D., \& DLR, R. TM, \& Brown, WJ (2009). Attitudes of young consumers towards SMS advertising. African Journal of Business Management, 3(9), 444-452.

Watjatrakul, B. (2011). Determinants of students' intentions to use a mobile messaging service in educational institutions: A theoretical model. World Academy of Science, Engineering and Technology, 49.

Zhang, J., \& Mao, E. (2008). Understanding the acceptance of mobile SMS advertising among young Chinese consumers. Psychology \& Marketing, 25(8), 787-805.

Yoga, I. M. S., \& Paramartha, I. G. N. D. (2018). Attitude, intention, and consumer behaviour of millennial generation toward location-based SMS advertising. International Research Journal of Management, IT and Social Sciences, 5(6), 60-70. https://doi.org/10.21744/irjmis.v5n6.373 


\section{Biography of Authors}

\begin{tabular}{|l|l|}
\hline I Made Sindhu Yoga is a marketing lecturer in Universitas Pendidikan Nasional, \\
Denpasar, Indonesia. He is interested in marketing communication, branding, and \\
tourism marketing. Moreover, he has done some researches related to event marketing, \\
city tourism destination competitiveness, community-based tourism, and tourist \\
behavior. \\
Email: madesindhu@undiknas.ac.id
\end{tabular}

